\title{
Moral Economies of Wartime Intimacy: One Facet of Gender in the Blockade of Leningrad
}

Jeffrey K. Hass, Ph.D., Associate Professor, University of Richmond (Richmond, USA), Professor St. Petersburg State University (St. Petersburg, Russia)

\section{Politics of Wartime Intimacy: From Deprivation and Desexualization to Resexualization}

Because it is political and simultaneously linked to one's sense of self and intimate relations with others, "gender" is never truly given or set. Even in relatively stable circumstances, social meanings of "man" and "woman" as physical, sexual, or status classifications can become objects of contestation in private spaces and public arenas. In the Blockade of Leningrad, these classifications were under a different kind of assault in fields and habitus: less from any political mobilization (highly problematic in the Stalinist era anyways), and more from a combination of demographic feminization of the city (as men entered the Red Army or died in mass numbers before women) and shifts in the value of gendered skills and positions. ${ }^{1}$ As they entered factories and took over men's jobs, and as they applied caregiving and homemaking skills to make efficient use of scarce food or food substitutes to help men and children survive (to the extent they could), women gained an increased sense of status that altered their own perceptions of their status vis-à-vis men and broader Leningrad society. Yet not only were senses of status and position shocked by the trials and tribulations of Blockade survival. Intimate 
signals and sensations of sex and sensuality had been disturbed, but their reequilibration was not always unproblematic. Sometimes resumption of normal signals of one's sex signaled normality and even relief.

If desexualization of sensations and relations was physiological, resexualization was political. Clearly starvation conditions affected sex drives and even physiological functions, such that Leningraders felt fewer inclinations towards sexual feelings and contact. We should not be surprised if women temporarily stopped menstruating, as their capacity for fertility was interrupted by such meager diets. ${ }^{2}$ Leningraders sometimes wrote that it was difficult to tell who was what sex in communal showers, so emaciated was everyone. Alongside physiological stress and even degradation were material and symbolic desexualization as well. Pre-war stocks of clothing had far less variety than in Western market economies, but there was still some variation between male and female clothing, for example dresses versus pants and types of shoes. Clothing in the first Blockade winter reduced such differentiation: as a rule, civilians wore what boots they could obtain, and style gave way to functionality for survival. In short, extreme duress and survival marginalized any sense of sexuality or sexual difference. The politics of sexuality and sensuality was lost in the politics of everyday survival.

Resexualization, on the other hand, was not a mere straightforward awakening of sexual feelings and impulses as diets and general lifestyles improved (however meagerly they did). It also involved tensions and contestation over norms of proper behavior in a wartime setting, when the survival not only of individuals but of the entire city (and Soviet nation) was at stake. Would sex and sensuality be an accepted part of everyday wartime and Blockade life - an outlet for tensions or source of compassion during intense duress? Or would sex and sensuality, invoking not only particular meanings of gender but also individual desires and autonomy, be considered a distraction from the war effort ${ }^{3}$ and even a profane attempt to bring normality to an abnormal context, possibly discounting (or belittling) the traumatic nature of the Blockade?

If the relation between gender and social position - status, tasks and practices in the division of labor, positions - was already complicated by Blockade tribulations, the relationship of gender meanings and positions to intimacy, sensuality, and sex was no less challenged. Those signals and perceptions were subject to processes of desexualization and resexualization. ${ }^{4}$ Demographic feminization and redistribution of men's and women's positions and practices in fields and contexts altered the meanings of possible and normal relations of intimacy. Was a nurse simply a woman (gender as biology) helping male soldiers return to health, or were these women nurses (gender as social) supposed to perform particular duties, some legal and legitimate and some more questionable from the puritanical perspective of Stalin's conservative gender norms? In no small sense, this was an issue of governmentality of bodies and mentalities, in which not only Soviet state and Communist Party but also average civilians ${ }^{5}$ played a role. Strained by demands of coordinating and mobilizing soldiers and civilians, with cadres at the front, ill, or dead, the Communist Party and Soviet state in Leningrad could not devote much quality time and effort to issues of sex, sensuality, and intimacy. To the extent there was any such effort, it was aimed at disciplining the occasional Party member for extramarital relations. ${ }^{6}$ Defining and regulating notions of legitimate wartime intimacy, in the end, was secondary to getting civilians to sacrifice labor and other resources to 
produce arms or other goods for the Red Army and to maintain social order. The politics of intimacy were a local and civilian affair.

Normal relations of intimacy in Stalin's prewar USSR were heteronormative and patriarchal: women were supposed to be feminine, men masculine. ${ }^{7}$ The war and Blockade shocked and began to reshape general gender positions, relations, and statuses. As men volunteered or were drafted in the Red Army, and then began to succumb to starvation more readily than women, the sexual demographics of the city shifted, feminizing Leningrad. By June 1942, roughly 75 percent of Leningrad civilians were female, and women made up from 75 to 80 percent of labor, depending on measures and data. ${ }^{8}$ Further, women's domestic responsibilities (making up a "second shift" after formal work) gave them important survival skills - in particular, the ability to find and economically make use of scarce food. These shifts in the distribution of women into men's positions and the increasing importance of their domestic skills for Blockade survival raised their status and senses of self-worth in families and workplaces, granting a new sense of empowerment amidst the deprivation and suffering of the Blockade. ${ }^{9}$ Patriarchy, like the city itself, was under assault. While these dynamics did not directly reshape intimacy - at least there is no irect evidence that it affected women's and men's senses of sensuality and intimacy - this did awaken in women a greater sense of self-assurance in making judgments.

In addition to homogenization of gender across institutional positions (e.g. women taking men's labor positions) was physical degradation from deprivation and hunger that made visual signals of sexual identification (physical and symbolic) more ambiguous. Between emaciation, militarization of consumer goods, and deprivation, Leningraders became confused as to who was which sex or gender - literally, the physical attributes of body form and clothing sent out visual cues at odds with those generally associated with "men" and "women." Although not an intended policy, the lack of variety of consumer goods, as well as functional needs (e. g. keeping warm, or clothed generally), meant men and women dressed more alike than even in the deficit days of the 1930s. Men and women were equally unkempt, especially when water was not flowing regularly to homes and bath houses, the bania, were closed or operating on uncertain schedules. Given that men and women were not presumed to be equally kempt - masculinity, especially for the working class, allowed men to appear relatively more shabby or disheveled (albeit not to the point of being slovenly) because of the nature of "men's work," i. e. in factories - the inevitable, relatively equal states of dishevelment the Blockade forced on Leningraders meant that visual cues could not signal gender differences as they had before. As well, emaciation brought men and women closer together in body image: between clothing and bodily appearance, it became increasingly difficult to tell who was a man and who was a woman, especially in the first winter.

A further manifestation of desexualization was the loss of sex drive due to starvation and stress. This was not something most Leningraders wrote about - a telling sign of the nature of sex and sensuality in the Stalinist era - but we would be surprised to see most civilians' libido hold up under such strains and suffering. Only the rare Leningrader commented on the loss of sex drive as a victim of the Blockade. V. F. Chekrizov noted in May 1942 that he had lost his sex drive in the first months of that year as hunger set in, and he was no longer even dreaming of sex - whereas earlier he would have gone crazy 
without sex for one or two weeks. ${ }^{10}$ This severe dearth of direct evidence is compensated somewhat by indirect evidence of a decline in sexual activity - in particular, the birth rate as a reflection of the effects of starvation. According to the city's Administration of Statistics, the birth rate initially plummeted from 25.4 to 9.6 births per thousand civilians in 1941 and 1942. However, the birth rate rebounded to 13.6 births per thousand in $1943 .{ }^{11}$ (The number of live births per thousand civilians was practically the same for each year - no small feat, is data are accurate.) By 1943, food supply into Leningrad had improved somewhat, and mass death and evacuations meant fewer mouths to feed. Civilians were still hungry, but they were no longer starving to death, and physiological functions were starting to return to normal. Physiologically and socially, dispositions to intimacy were reawakening - but now in a new context.

\section{Moral Economies of Contentious Resexualization}

That desires for sex and intimacy more generally should wane with hunger and desperate survival is no surprise, and the occasional Leningrad admitted as such. After noting how his sex drive had collapsed in 1942, V. F. Chekrizov noted that his sex drive returned as food supply and his diet improved. At least he could now conceive of sex once again and write about it in his diary. ${ }^{12}$ Less straightforward but no less important, Olga Epshtein wrote in June 1943, "This month, after a 20-month break, I became a woman again." She thought this would be painful, but it was not. "This means that I am becoming a normal person again." ${ }^{13}$ This might seem cryptic if one did not do the math and note that the "20-month break" began in October 1941, when rations began to plummet. This suggests that Epshtein referred to menstruation. That her remark was cryptic in her own private diary - just as it had been in the first weeks of war, when she hinted at menstruation as proof that she was not pregnant ${ }^{14}$ - reveals her own discomfort talking about such an intimate (and gendered) physiological process. Menstruation, far from being a cold fact of female human physiology, was deeply personal and imbued with a sense of different status. The sense of being a normal or real "female" or "male" was not limited to one's private physiological sensations (although I have yet to find men's comments about diminished sexual faculties — but men had difficulty admitting any loss of strength). Other signals and observations could contribute to uncertainty about "objective" sex and gender.

If desexualization was disconcerting, albeit seemingly of a piece with the rest of the Blockade experience, resexualization - the return of symbols and signals of one's "sex" - was not without its own troubles. Once there was enough food in the city to make survival possible (i. e. by late spring 1942), then first signs of the return of normal dress and appearance appeared. V. F. Chekrizov wrote on May 1, 1942, that more employees were coming to work at Sudomekh in the same clothing as they had before the war, e.g. ties and suits. As they walked in public, some women were wearing hats and cosmetics (e.g. lipstick). Chekrizov also noted seeing some people drunk in public - but given the hell all had just endured, this did not seem so unpleasant as before. ${ }^{15}$ Yet significant reappearance of more gender-specific appearances would have to wait until material conditions further improved. Unsurprisingly, as burdens became lighter by 1943 , there was a reawakening of intimate desire, whether sexual, platonic, romantic, or otherwise, 
among Leningraders. The Party and state were too preoccupied with the war effort to enforce particular gender practices - even the legal prohibition against abortions seems to have been enforced only in the breach - and civilians were left to reconstruct and propagate rules and relations of practicing femininity, masculinity, and intimacy. For some women, intimate, romantic relationships were important enough that the highs and lows of the dance of love became important parts of their narratives - especially in 1943 and 1944, when a modicum of stability had finally emerged (even if without much improvement in living conditions). In a context of some stability and certainty, it was possible to turn back to more "everyday" or "normal" desires and pursuits: when one did not have to (or did not care to) worry about whether one would live to the next day, then time horizons expanded and thoughts could drift beyond bread and shelter. For some women and men, this meant more time for work or other patriotic activities; for others it meant evacuations or attention to families. For others - especially women who were single or whose spouses were missing or dead - this meant the search for a companion who would be closer and more intimate than a good friend could be. Perhaps the clearest example of the importance of wartime romance, and all its complications, is the third volume of Nina Kobyzeva's diary, in which relations with a young male named Petya take up much of her narrative as Blockade life stabilized after January $1943 .{ }^{16}$

Kobyzeva's was far from an isolated story. Tatiana lanovich also did make some mention of troubled relations with "Alesha" and "Andrei" in her diary. (Whether one or the other was a husband or former husband is difficult to judge. There is enough feeling to suggest emotional ties, but not enough to suggest a spouse.) In late 1941 she recalled one time together with Alesha when he was away and wrote about missing him and how soon after he briefly came by her abode. Alesha did not make much of an appearance again until February 1943, when again she wished Alesha was with her. By summer 1943 Alesha was out of her life and "Andrei" entered the picture, writing her many letters, and she wrote of missing him - until their relations dissolved and she returned to thinking about Alesha once again, although she admitted in late 1943 to being heartbroken over Alesha, whom she hoped one day would reciprocate her feelings. She had high hopes he might come by for New Year's - apparently he promised something like this - but he did not show, signaling that perhaps there were and could not be personal relations with him. Not long after, she wrote how she wished she could erase Alesha from her diary, and that she needed to be stronger. Yet she still saw him now and then after the end of the Blockade, and she conceded that he remained central to her life; painful thoughts about him were offset, for the moment, by the news of military victories against Hitler and eventually by his admission that he loved her. What happened further is a mystery, for her Blockade diary ends at this point, not long after the Blockade itself was lifted. ${ }^{17}$

As short or in passing as they might seem, lanovich's comments about Alesha and Andrei were recurring and were mixed with other observations or comments about Soviet cities being taken back from the Germans, bombs still falling on various parts of the city, a friend's son in and out of the hospital, receiving a medal for her factory work, and other military news. Just as bombs and pain were part of the everyday landscape, so were various feelings and practices of romance, unsatisfying as they might have been. That lanovich thought she needed to eject Alesha from her life and "be strong" suggests the importance of this relationship - perhaps any - to her sense of self. And 
lanovich was not a weak person by any means - like Kobyzeva and Epshtein, among others, she had important responsibilities and suffered the hardships of the Blockade with little open bitterness in her diary. Note that she did not question this need for male companionship, in contrast to questions she had about Leningraders who had left the city and wanted to return after January $1943^{18}$ - or if she did question this need, she did not write about it. Her sense of self was anchored in her duty to city and country, in her relations with family and coworkers, and with Alesha (and Andrei for a short while). She did not mention any sense of pressure from social cues and others' behavior driving this anchoring; we can only guess how this came to be part of her habitus, but one important part it was.

Were resexualization and intimacy purely private affairs, certainly there would have been some tension: trust strained by hunger and strains of war, and sometimes distance if one mate had evacuated. But resexualization, it turns out, was contested, in no small part because it involved public signals, including how one dressed, with whom one spent any time, and the signals one sent to that other and to others who could observe games of intimacy (e.g. flirting). Fields did clearly enter into personal and romantic relationships when Leningraders competed over the rules of the game: if romance was organized striving, then different people had different ideas of how to strive for companionship. "Femininity" and "masculinity" in Leningrad were linked to tastes in appearance and practice. Some women who had the means might use this for tactical reasons - employing gendered stereotypes of the "attractive" woman to their advantage. Other women might respond negatively to "femininity" out of status insecurity or disgust that someone would elevate personal taste over the war effort (i. e. focusing resources and effort on sensuality rather than production or social work) - all of which suggests that notions of "normal" gender practice and appearance were intertwined with positions and practices in various fields.

In his diary account of the Blockade, Vladimir Miasnikov complained about his wife's lack of trust and faith in him - a likely result of distance, stress of Blockade and war, and gendered expectations of how women were supposed to relate to men. This was only part of his judgments of women's expected versus real behaviors, especially regarding relations and intimacy. No sooner had he written negatively about his wife, than he was commenting on women's wartime behavior generally. On November 9, 1942, he wrote about reading two articles that he felt the young should read. The first, titled "Freak" and appearing in Komsomolskaia pravda, discussed a woman who thought only about "the gender question" and nothing else. She had a husband at the front and a favorite with whom she had fallen in love. She wrote about "erotic feelings" for her husband and an "ideal situation." Whether this was a real woman and occurrence or a parable is unclear. Miasnikov likely was still burning over his wife's cold relations and his suspicions of her actions elsewhere in the USSR. For Miasnikov, the real question was what she was really doing: "What is going on now in Leningrad! Women go insane and throw themselves at the first man they meet, not thinking about anything: not about their husbands who are at the front, living through all miseries and to whom in their time they were 'vowing' [i.e. marriage vows] - 'I love you and will be yours forever' - and not about children... and not of their honor and consciences." ${ }^{19}$ The second article, from Pravda and titled "The Wife," showed the proper way for a woman to live; alas, Miasnikov 
did not provide detail on this article. His sense of injustice was fueled by suspicions and fears that soldiers - perhaps himself one day - would return from the front as invalids, but no one would greet them, thank them, and care for them. In particular, there would be no wife to repay this debt of military service. Miasnikov's gendered perceptions of proper positions and relations between men and women, especially soldiers and wives, is not unique to the Red Army at this time.

One could dismiss Miasnikov and others as males feeling acute tensions of war and a far-away wife possibly not behaving in a proper way, i.e. sensual and subservient to her formal mate. Yet contention came not only from men. Women could be judgmental of other women for their acts or signals of sensuality. In her account of the Blockade experience, Mariia Konopleva more than once cast a critical eye towards other women, whether they were trading rumors in food lines and bomb shelters or complaining about their hardships in a besieged city where all had to sacrifice to survive and defeat the enemy..$^{20}$ The editor of the Rabochii textile factory's newspaper, one comrade Aliabova, quickly raised the topic of improper intimacy in her discussion of Party work at her factory. Her Party boss, Sofiia Glazomitskaia, gave her entire life to Party work at the factory, but not all other workers and Party members followed her example. One woman was warned against have illicit affairs with a married sailor. Apparently, someone in the factory's Party cell requested a formal inquiry into the sailor's background to find out whether he was married. Glazomitskaia, whose was married to a sailor (but who was missing in action), issued this woman a formal warning. ${ }^{21}$

Sometimes one's desire or capacity to frame normal intimacy was a product of one's own senses of fit with those rules and relations. If one had few relations, one might feel less likely to be totally loyal to rules of legitimate intimacy. Reflecting on her own loneliness - her husband and son were dead or missing - Aleksandra Zagorskaia briefly mentioned in June 1943 how her friend Nina left her husband and family for a lieutenant 18 months earlier. The lieutenant eventually abandoned her for someone else, leaving her life "broken," but Zagorskaia did not pass judgment on Nina's actions. Rather, fate was to blame: "Life cruelly mocks people." Perhaps she was not so judgmental because her own loneliness led her to appreciate those brief moments when she felt happy. On this day, June 25, 1943, Zagorskaia wrote that she did feel alive - but who knew how she would feel or live tomorrow? The lesson was to live for what we had at the moment - and perhaps, for this reason, she was not inclined to pass harsh judgment on Nina. (As if to underscore this point, a few days later she wrote of feeling ill and of the pain she felt over her son Pavlik, of whom she had no news and feared was missing in action or dead. $)^{22}$

\section{One Woman's Account of Norms of Intimacy: Olga Epshtein}

While I have cited a few accounts - space constraints forbid a more detailed discussion - I now go into a little more detail using a single account from a Leningrader who happened to bequeath future generations a detailed account of the personal and collective dramas that made up the Blockade. Olga Epshtein was a single mother to a young child whose care and health constantly worried her, but the demands of work and lack of help (e.g. no mother or other family member to help raise the child) meant she left him in state-run nurseries for weeks on end. She was a factory worker at a military 
enterprise, and from her description of her additional work and responsibilities, it seems she was also a Stakhanovite, with all the extra demands that status brought. Finally, she was a Party member, which brought additional obligations and a moral code to which she had to adhere. In the first month of war her husband Misha signed up with the Red Army, and soon he was sent to the front. She lost communication with him quickly, and only several years later did she receive definitive word that he was dead - although she had suspected as much for the duration of the Blockade, she always held out hope that he would return home. Misha's absence meant the possibility of a desire for romance, as well as possible guilt at pursuing it (until she later received official word that he was dead). Her identification with the Party and Stakhanovism also suggests that she held to a moral code of disciplined behavior and dedication to the requirements of Party and state, especially in wartime. In her perceptions of herself and others, resexualization was likely to compete with other desires and norms, and be contested.

And so it was. To cope with her suffering and tribulations, Epshtein invoked a frame of normal, proper female behavior that fit with the Party's message of discipline as well as a more traditional, and also disciplined, sense of femininity. In particular, Epshtein raised these themes in her diary when she witnessed or sensed that others were not quite pulling their weight for the war effort - and which could also mean that they did not worry (or care) about a young child and a mate lost at the front, as did she. ${ }^{23}$ The stresses she felt from her Blockade experience were augmented by a gendered conscience. When she could not fulfill one set of duties adequately, she felt pangs guilt, sometimes manifested in bitterness towards herself and towards others who were fulfilling their duties to society and the war effort.

Epshtein's sense of judgment could seem harsh at times and reflect a basic binary of sacred-profane or proper-immoral. Her assessments of others' moments of intimacy, or at least companionship and sensuality, could evoke such feelings, borne not only from a sense of propriety but also from bitterness about her own difficult and lonely situation. ${ }^{24}$ From her perspective, relatively more sensual modes of dress and behavior might make a woman akin to a prostitute, even if these women might simply have been pursuing a survival strategy in these difficult times (i.e. trade intimacy for vodka or food) or merely indulging in a momentary sensation of and even agency, at a moment when Blockade deprivation made both difficult. As a rule, Epshtein's views about such moments of possible intimacy epitomized paradoxes of resexualization as source of contention and as signal of normality. In August 1943, when Leningraders would have reawakened to possibilities of intimacy, Epshtein wrote the following comment in her diary: "Many young ladies and girls do not take the honest path. They become friendly with military men and enter relations with them [i.e. prostitution] only to eat. I cannot do this. It is better that I go hungry, but I do not have the desire to sell myself for a piece of bread." 25 Intimacy was strategic, not emotional and authentic - how could it be, in Blockade conditions that, in her experience, cause only pain as mates went missing at the front? Yet soon after she relented and bought a dress at the market (rynok) rather than food. She was eating better (and menstruating again), and she felt that she was looking more like a woman (and receiving men's glances as a result). A new dress was a logical next step. ${ }^{26}$ She noted how wartime deprivation forced men and women to wear the same drab style of clothes: "In their clothing, women do not differ from men." Yet she 
noticed later in 1943 how women started to dress once again in a more feminine manner. Epshtein herself felt like "a real baba" in her unisex Blockade clothing (e.g. vatnik and cheap, rough jacket), despite having bought a dress earlier. ${ }^{27}$ At the beginning of March 1943, Epshtein remarked that women were beginning to dress better once again, likely because soon it would be March 8, International Women's Day. In fact, one technologist at her factory briefly flirted with her - and because he seemed a little like her missing husband Misha, she showed some interest. Yet before long, she decided to abandon this possible relationship to get back to "honest work." 28

This contradiction between critical judgment and indulgence in practices related to intimacy and sensuality captured the broader contradictions of gender, intimacy, and the extreme conditions of the Blockade and a war for survival. The reawakening of sensuality and intimacy would be only human: between biological drives, general need for companionship, and intimacy as a release in moments of duress, we would be surprised were there little intimacy, even if strategic. Yet this could be seen to normalize the otherwise abnormal, traumatic, and even evil circumstances of the Blockade. Not only was intimacy a distraction from support for the war effort; it meant that there could be something normal in the Blockade, which could hint that normality was possible. Symbolically this was a lot to swallow; even worse for those who suffered the loss of an intimate Other. Epshtein did not make such claims so openly, yet she hinted at this very contradiction. At one point, while watching couples walking together along the street, Epshtein mused about the unfairness of fate and the degradation of norms and morals: "If you look at last year, they were dragging the dead, and this year girls still young are dragging babies wrapping in blankets. That's war for you. For a piece of bread one gives herself, while another has money to burn. Speaking for myself, have kids - cadres will be needed." 29 Later she wrote that she had forsworn romance until the trauma of war and Blockade were over - and yet, at the same time, she also admitted that she envied women who were romantically engaged..$^{30}$ In June 1943 Epshtein could not appreciate a newspaper clipping proclaiming praising her work ethic because she suddenly felt a twang of longing for Misha, and so she did not care about work or praise. Wondering whether he was alive or dead, she decided that she would "behave well until the end." 1 Yet again, she wrote of seeing more men and women together in public: Leningraders were rediscovering relationships and intimacy that Epshtein were foreswearing for the moment. ${ }^{32}$ Later that summer, she refrained from pursuing an initial attraction to a coworker whose family had been evacuated, ${ }^{33}$ even though others around her were having affairs, including a superior. ${ }^{34}$ Not long after, she turned on several female coworkers: "Who are the military workers? They are girls, ladies, who have no training or experience, but simply supported by connections [blat]. They have many rights, and they want all their demands fulfilled." 35

For all her moralizing - borne of personal morality and pain - Epshtein did not entirely deny an allure of gendered sensuality even in wartime, perhaps because this would provide a brief moment and sensation of that calm and normality before the war. In August and September 1943, having eaten better and having accumulated reserves of food and other goods, she returned to the rynok for more items of clothing that were relative luxuries. In August she bought a skirt for 600 rubles, and she later wrote of this as an "irony" - while others were eating, she was buying a skirt. Later she bought a 
dress for 400 rubles. In September she bought a pair of boots. They were not cheap the boots cost 1500 rubles, and she traded a half a liter of wine, 600 rubles, a pack of tobacco, and 800 grams of bread for them. Granted, the state was caring for her son Edik in a nursery, and she had no one else to care for at home - but this was no small sum in rubles and in kind to trade for something that was more a luxury than survival necessity. (The boots could be considered an investment to trade away on a rainy day - but she never expressed this strategy.) She even admitted in her diary that felt odd wearing boots to work in wartime, but her days were relatively boring now - there was no immediate need for other types of shoes. This act of a purchasing a pricey consumer good beyond what she needed for survival was both an expression of a move back towards some form of normality, as well as an expression of some degree of normal, pre-war femininity. ${ }^{36}$

This contradiction of contentious resexualization was not a fleeting affair. Even after the European war had ended, Epshtein still felt a contradiction between an intimate sense of self still linked to her late husband, and reemerging sensual relations between men and women in Leningrad that mirrored a post-Blockade normalization of other facets of Leningrad life. Epshtein wrote at length about one encounter with another man on a tram in July 1945; I will not give all details, but rather the basic thrust of her story. On that July day, she was riding the tram from Troitskoe Pole, the district of her formal residence, from where she needed documentation about her housing registration for 1932-1941. On the tram, a male struck up a conversation with her. He remarked that she looked young and should get something out of life. Apparently, one way to do so would be to spend time with him, were she free that evening. He asked if she had a husband. She responded that he was dead but had left a "legacy" (i. e. Edik, although he was not Misha's biological son). Edik was away at a summer camp, and when she resisted his suggestion that they both go to Edik and take a walk with him - apparently a clumsy attempt to play the role of father in the family — he asked if she was "materially secure." Tired of his increasingly forward questions and manner, Epshtein got off the tram, but she could not put this interaction behind her immediately. She reflected on how Misha's death had affected her sense of self and intimacy: "All the same, in my soul a spark had been smoldering, but now it has gone out."37

\section{Conclusion}

Like many other Leningraders, Epshtein clearly experienced the human desire for companionship - but that desire was filtered through lenses of gender and a sense of propriety in a context of desperate wartime survival. Romance was a luxury, and this was a moment for deferred gratification. This was but one of the many contradictions and tensions Leningraders confronted in attempting to survive the combined assault of a German army out to eradicate them, a regime out to exploit their energy and efforts (as well as identities), and the effects of material deprivation. Yet those tribulations were not only personal. They were social and political as well. These feelings and dispositions regarding intimacy and resexualization were directed not only at oneself but also at broader social relations and practices - that is, at fields of social relations, practices, and meanings of legitimate and normal. While Soviet politics was not pluralistic, and so these dispositions and judgments did not find outlets in or generate broader public 
discourse, they were still present - and despite that absence of public discourse, were shared. These contradictions between resexualization and deferred gratification for country and for Stalin generated political contention - not at the level of Party debates or state policy, but in the politics of everyday perceptions and practices, and in the discourses of diaries. Formal policies, directly and indirectly, still favored men. Soldiers (overwhelmingly male) had higher status than civilians and gained more resources, and men remained dominant in the higher ranks of the Party and state. Yet women had seen their own status rise as they helped the city survive. Gender meanings, relations, and statuses were being unmoored in these everyday sites and fields of practices. Intimacy and resexualization was only one front in this gender struggle.

One interesting facet of gender in the Blockade is how it reveals the complex intersection between the subjective, the objective, and the relational, especially in wartime. ${ }^{38}$ The subjective: the sense of one's identity, position, and essence. The objective: the influence of physical and material forces, such as the effects of starvation on the body, or the lack of a choice of clothing that would allow one to construct gendered symbols and signals. The relational: that gender also exists in how actors perceive each other and what "masculine" and "feminine" should be, as enacted not only through particular behaviors (themselves affected by such objective conditions as starvation) but also through signaling one's gender identity and expected behavior through what they wear. How World War II affected these dimensions of gender - from concrete cases such as the Blockade to general dynamics across the entire USSR, from those shocks during the war to the echoes in the post-war era - require far more study. The goal of this paper has been to scratch the surface in one case. More awaits us in myriad archives.

1 Jeffrey Hass, "Война и воспроизводство гендерных отношений: Случай блокадного Ленинграда," in Маленький человек и большая война в истории России (середина XIX - середина $X X$ в.), под редакцией В. В Ларина и др. (СПб.: Нестор-История, 2014), с. 435-447.

2 This was almost never mentioned in diaries, although Olga Epshtein hinted at this twice, once at the outbreak of war when she feared she was pregnant, and then again later in the Blockade. I return to this second moment below.

3 On sex, sex drive, and political mobilization, see Jeff Goodwin, "The Libidinal Constitution of a High-Risk Social Movement: Affectual Ties and Solidarity in the Huk Rebellion, 1946 to 1954 ," American Sociological Review vol.62(1997), pp. 53-69; Jeff Goodwin, James M. Jasper, and Francesca Polletta (eds.), Passionate Politics: Emotions and Social Movements (Chicago: University of Chicago Press, 2001).

4 I draw in part on concepts of sexual fields and sexual capital, although I have disagreements with proponents of this concept. John Martin and Matt George, "Theories of Sexual Stratification: Toward an Analytics of the Sexual Field and a Theory of Sexual Capital," Sociological Theory 24 (2006), pp. 107-132.

5 For sake of space, I leave out relations between soldiers and civilians, which introduce additional facets of meaning and practice. State authorities (e.g. police) and civilians did note how some relations between civilian women and male soldiers were often based on exchanging food or vodka (or some other similar good) for intimacy (from walks down Nekskii Prospekt to sex).

6 Е. g. ЦГАИПД СПб. Ф. 4000, Оп. 10, Д. 327, Л. 37.

7 The incidence of single-sex relations, even if fleeting, is a question of interest that is nearimpossible to address, given the lack of data. While single-sex intimacy faced legal and normative taboos (and do once again, alas), given how Leningrad was demographically feminized, and given 
the degree of duress, it is not inconceivable that there were fleeting intimate, single-sex encounters between women for relief from the stresses of such a horrific situation.

8 Черепенина Н. Ю. Гендерная статистика блокады // Женщины и война. О роли женщин в обороне Ленинграда. Под редакцией М.И.Боженковы, А.И.Бурлакова, А.Р. Дзенискевича, А.Н.Рубцовы, Т.А. Пострелова и И.Д. Ходановича. СПб., 2006.С. 235-244; Манаков Н.А. В кольце блокады. Хозяйство и быт осажденного Ленинграда. Л., 1961.

9 Jeffrey Hass, "Anchors, Habitus, and Practices under the Siege of War: The Story of Women and Gender in the Blockade of Leningrad.” Mimeo, Department of Sociology and Anthropology, University of Richmond.

10 Чекризов В.Ф. Дневник блокадноговремени. Труды Государственного музея истории Санкт-Петербурга. СПб.: Искусство России, 2004. С. 75.

11 Сf. ЦГА СПб. Ф.4965, Оп. 3, Д. 105, Л.24-32, cited in Дзенискевич А.Р., Ленинград в осаде. Сборник документов. СПб: Лики России, 1995. С. 352. A per capita birth rate does not take into account evacuations: While there were 67,899 births in 1941 and 12,659 in 1942, there were only 7775 in 1943 because there were far fewer civilians remaining in Leningrad.

12 Чекризов. Дневник блокадноговремени. С. 75.

13 ЦГАЛИ СПб. Ф. 107, Оп. 3, Д. 325, Л. 9.

14 ЦГАЛИ СПб. Ф. 107, Оп. 3, Д. 323, Л. 7, 10.

15 Чекризов. Дневник блокадноговремени. С. 74.

16 ГММОБЛ РДФ. Акт 76-07, т. 2, Л. 42-47.

17 ЦГАИПД СПб. Ф. 4000, Оп. 11, Д. 122, Л. 14-15, 26, 29, 31, 32, 33, 37, 39, 40-41, 42, 45, 49,51 .

18 ЦГАИПД СПб. Ф. 4000, ОП. 11, Д. 122, Л. 28-29.

19 ЦГАИПД СПб. Ф. 4000, Оп. 11, Д. 74, Л. 84.

20 Е.g. РНБ ОР. Ф. 308, Д. 1, Л. 125.

21 ЦГАИПД СПб. Ф. 4000, Оп. 10, Д. 327, Л. 37.

22 ЦГАИПД СПб. Ф. 4000, Оп. 11, Д. 33, Л. 31.

${ }_{23}$ One facet of Epshtein's account, and not unique, that I cannot explore here is a sense of existential ressentiment embedded in narrative logics of Blockade survival — a sense of ressentiment not as strong in later reminiscences.

24 Given Epshtein's relations to the Party and Soviet socialism, this is not that surprising. She was critical of various Party officials for their lack of competence or care in their work; and while she did not invoke socialist categories of dialectical materialism in her diary, she was concerned about class justice. Thus, it is possible that she shared the rather prudish sexual politics of Stalin-era socialism, i.e. conservatism not that far from Victorian norms.

25 ЦГАЛИ СПб. Ф. 107, Оп. 3, Д. 324, Л. 31.

26 ЦГАЛИ СПб. Ф. 107, Оп. 3, Д. 324, Л. 32, 34.

27 ЦГАЛИ СПб. Ф. 107, Оп. 3, Д. 324, Л. 67, 72.

28 ЦГАЛИ СПб. Ф. 107, ОП. 3, Д. 324, Л. 72.

29 ЦГАЛИ СПб. Ф. 107, Оп. 3, Д. 324, Л. 93.

30 ЦГАЛИ СПб. Ф. 107, Оп. 3, Д. 324, Л. 94.

31 ЦГАЛИ СПб. Ф. 107, Оп. 3, Д. 324, Л. 95.

32 ЦГАЛИ СПб. Ф. 107, Оп. 3, Д. 324, Л. 96.

33 ЦГАЛИ СПб. Ф. 107, Оп. 3, Д. 325, Л.9.

34 ЦГАЛИ СПб. Ф. 107, Оп. 3, Д. 325, Л. 17-18.

35 ЦГАЛИ СПб. Ф. 107, ОП. 3, Д. 325, Л. 59.

36 ЦГАЛИ СПб. Ф. 107, Оп. 3, Д. 325, Л. 34, 39-40.

37 ЦГАЛИ СПб. Ф. 107, Оп. 3, Д. 326, Л. 29.

38 That war could affect gender meanings and relations was not unique to Leningrad in the Blockade. For some other histories, see: Susan Grayzel, Women's Identities at War: Gender, Motherhood, and Politics in Britain and France during the First World War (Chapel Hill: University of North Carolina Press, 1999); Maureen Honey, Creating Rosie the Riveter. Class, Gender, and Propaganda During World War II (Amherst: University of Massachusetts Press, 1984); Victoria Ott, Confederate Daughters. Coming of Age in the Civil War (Carbondale: Southern Illinois University 
Press, 2008); Angela Smith, The Second Battlefield: Women, Modernism, and the First World War (Manchester: University of Manchester Press, 2000).

\title{
FOR CITATION:
}

Hass J. K. Moral Economies of Wartime Intimacy: One Facet of Gender in the Blockade of Leningrad, Modern History of Russia, no. 2, 2017. P. 68-80.

\begin{abstract}
The Blockade of Leningrad was a tragedy that significantly affected all aspects of everyday civilian life. One such area was gender: from jobs to families and much more, the roles, identities, and practices of women and men shifted, sometimes profoundly. One such area was intimacy and sensuality. This paper briefly explores how the combination of material deprivation and shifts in women's responsibilities and status in the besieged city created competing norms vis-à-vis the "proper" nature of sexuality and intimacy. In particular, after desexualization in the first Blockade winter - where sex drives and senses of femininity and masculinity were under assault by severe food and material deprivation - a resexualization followed once food availability stabilized. However, the return of senses of sexuality and intimacy was not without tension: in particular, a tension over the legitimate position of intimacy and sensuality in relation to deferring such feelings to discipline oneself and devote energy and attention to the war effort. In the sphere of everyday life, a politics of resexualization began to emerge in Leningrad in 1943.
\end{abstract}

Keywords: blockade, Leningrad, moral, deprivation, desexualization.

Author: J. K. Hass - Ph.D., Associate Professor, University of Richmond (Richmond, USA), professor, St. Petersburg State University (St. Petersburg, Russia); jhass@richmond.edu

\section{References:}

Hass J. "Voyna i vosproizvodstvo gendernykh otnosheniy: Sluchay blokadnogo Leningrada" in Malenkiy chelovek i bolshaya voyna v istorii Rossii (seredina XIX - seredina XX v.). Ed. V. V. Larin and oth. (St. Petersburg, 2014).

Goodwin J. "The Libidinal Constitution of a High-Risk Social Movement: Affectual Ties and Solidarity in the Huk Rebellion, 1946 to 1954”, American Sociological Review, vol. 62, 1997.

Passionate Politics: Emotions and Social Movements, Eds. Jeff Goodwin, James M. Jasper, and Francesca Polletta (Chicago, 2001).

Martin J., George M. Theories of Sexual Stratification: Toward an Analytics of the Sexual Field and a Theory of Sexual Capital, Sociological Theory, no. 24, 2006.

Cherepenina N. Yu. 'Gendernaya statistika blokady' in Zhenshchiny i voyna. O roli zhenshchin v oborone Leningrada, Eds. M.I. Bozhenkova, A. I. Burlakov, A. R. Dzeniskevich, A. N. Rubtsova, T. A. Postrelov, I. D. Khodanovich (St. Petersburg, 2006).

Chekrizov V. F. 'Dnevnik blokadnogo vremeni' in Trudy Gosudarstvennogo muzeya istorii Sankt-Peterburga, Iss. 8 (St. Petersburg, 2004).

Dzeniskevich A. R. Leningrad v osade. Sbornik dokumentov (St. Petersburg, 1995).

Grayzel S. Women's Identities at War: Gender, Motherhood, and Politics in Britain and France during the First World War (Chapel Hill, 1999).

Honey M. Creating Rosie the Riveter. Class, Gender, and Propaganda During World War II (Amherst, 1984).

Ott V. Confederate Daughters. Coming of Age in the Civil War (Carbondale, 2008).

Smith A. The Second Battlefield: Women, Modernism, and the First World War (Manchester, 2000). 